\title{
A Model to Identify Factors Influencing Customers' Bank Selection Decision: Case Study of Fereshtegan Credit and Financial Institute (with the Former Name of Arman)
}

\author{
Hossein Najafi \\ MA of Business Management, Marketing Major - Farabi College of Tehran University \\ Email: najafi.hossein@ut.ac.ir \\ Fatemeh Rahman \\ MA of Business Management, Marketing Major - Farabi College of Tehran University \\ Email: rahmani.fatemeh@ut.ac.ir \\ Mojtaba Maleki \\ Lecturer (Professor) of business management (Marketing Major) \\ Email:maleki.dba@gmail.com
}

Doi:10.5901/mjss.2016.v7n3s3p177

\section{Abstract}

The main goal of each organization is to create a strong relationship between its products and the customers. The extract and result of this relationship will be customers' loyalty and commitment toward (to) organization products. Such a commitment will be create during a process which involves (includes) 3 steps: 1.customer familiarity with product, 2.getting knowledge about that product, and 3.prefer that product to others. In case of this process success (successfulness), customer loyalty, the success of the organization and the rivals and competitors disappointment will be ensured. The aim of this article is to present a model to identify the factors influencing the customers of Fereshtegan financial institute for selecting their bank. For this purpose, this research is done by asking questions and with descriptive-survey method. The population of this study is consist of the customers who have at least 10 million rials facilities in one of the Fereshtegan financial institute branches or have opened an account with at least 10 million rials deposit in one of these branches. The data analysis is done in two levels of descriptive and inferential statistics, and by use of SPSS software, $t$-student test and Friedman test for prioritizing the effective factors. The results reveal that there is a positive significant relationship between the factors (such as bank employees' behavior, the cost of bank services, special services offered by bank, and the reliability of the bank or bank goodwill) and selecting the bank by customers of Fereseshtegan financial institute. Also the results show that theses factors can affect customers' bank selection decision. According to Friedman test, prioritizing the effective factors by the customers of Fereshtegan financial institute are not the same. According to the factors rating average, we can conclude that the bank employees' behavior factor has the most utility and also has the highest priority and the bank reliability factor has the lowest priority.

Keywords: bank reliability (bank goodwill), bank selection, Fereshtegan financial institute

\section{Introduction}

Understanding, recognition and reliability of the business parties is one of the most important essential elements in business world. Goodwill, good reputation and commitment of the parties to high ethical and professional standards are necessary for the continuation of a good business relationship in a path which both parties (both sides) will benefit from its advantages. And financial system is not an exception.

Banks as one of the constituent elements of the financial system are very vulnerable in this field. Inability of the bank for correct management of reputation risk can lead to irreparable consequences. Ordinary customers are entitled to consider the reputation and reliability of the bank when they want to choose a bank for their business. On the other hand, the banks are entitled and obliged to identify the customers' identity, otherwise they may be subject to reputation, operational, legal and concentration risks. This can result in high financial expenses (Arjmandnejad, 1384)

In recent years, banking industry has witnessed sever competition along with many opportunities and threats. Obviously, no bank can provide all possible services and of course no bank can be the best in the field of (area of) the 
provided services. Banks can adopt the best strategies by evaluating their strengths and opportunities in the market in order to achieve a proper competitive position in the market.

Marketing is a sub-system in all banks. Such a sub-system interacts with other sub-systems and therefore with the main system of the bank which is bank integrity (bank totality). Improving marketing system will improve other systems and therefore the whole bank. On the other hand, other systems improvement can influence marketing system. Since competition has increased through (via) technology, so banks should adopt market-oriented approaches in order to differentiate their services and maintain their position in the market. This leads to a great emphasis on quality and efficiency to gain a proper competitive position. Achieving an appropriate position in a competitive market requires esteeming (put value) the current and potential customers based on their needs and requirements. If we want to take the right localization decision, we should be aware of the following items:

1. Customers use what (which) kinds of dimensions and aspects to evaluate the competitive marketing?

2. How much is the importance of these aspects in the decision-making process?

3. How the customers compare us with our competitors based on these aspects?

4. How the customers select their bank based on these information?

The ability of the bank to provide desired services is very important, valuable and decisive for customers. Therefore, for being efficient, banks should gain sufficient information about customers and their needs and also develop the relations with them. Improvement of relationship marketing in bank will be obtained through the development of relationship with customers. Maintaining the relationship with customers is a long term issue, and the managers should consider its future consequences instead of its current outcomes. On the other hand, the quality of the relationship with customers is measured by customer satisfaction. Methods of maintaining the relationship with customers are different due to variant cultures. Since our country has an old and time-honored historical background and since our people are very kind and friendly, so Iranian banks put great importance on social and personal interactions in order to strengthen their relations with customers. Even the banks employees' behavior is one of the most important factors of customer retention. Therefore continuous social interactions such as: meetings, formal and informal invitations to events, participating in customers' ceremonies, prize and gift awarding, creditworthy awards, economic advice and consultation, and explaining the bank services is very important.

Bank service explanations and specially describing e-banking services is mandatory and compulsory in modern banking. Customers of the banks should be familiar with the bank services through mass media. And on the other hand, the banks should explain their services for customers from a to $z$. They should never think that the customers are aware of all banking services. Any cost allocation to inform customers via press, newsletters or mass media and especially ebanking explanation result in: lack of customers' physical presence in bank branches, customer awareness about (of) bank services, time saving and work speed improvement. All of abovementioned factors increase the bank productivity and customers' satisfaction. All these savings and thrifts will result in too much profitability for both parties (both sides) in macro levels.

\section{The theoretical framework and research model}

Study of the consumer behavior plays an important role in marketing, because consumer marketing requires a correct understanding of consumer needs and demands. The importance of understanding the customers' needs is a major factor in marketing, since in marketing definition it is considered as a human activity which can satisfy all the needs and requirements through exchange processes. Two key activities are emerged from this definition, which are related to marketing: First, the seller tries to satisfy the target market needs. Second, marketing involves the study of exchange process through which the two parties transfer some resources to each other. To succeed in exchange process, marketers should have a correct understanding about the factors which influence the customers' needs (Movon \& Minor,1993). Creation of strong loyalty and commitment between a brand and a group of special customers has three stages: 1.The customer become familiar with the brand name, 2. He/she gets knowledge about that brand, 3. He/she prefers that brand to others, 4 . If the created relationship between the customer and the brand is successful, the customer will be satisfy and loyal to that brand. (Alreck \& Settle,1999) 


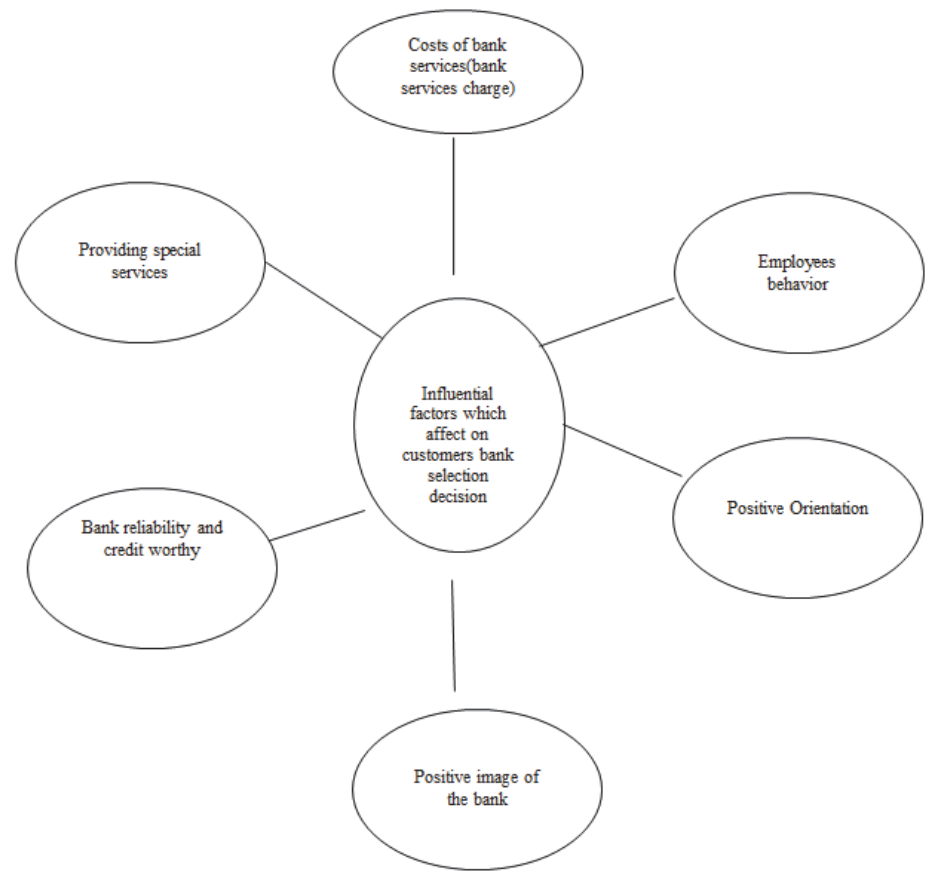

Model no.1. The conceptual model of the research (Ranjbarian \& Gholami)

During recent years, study and research about customers' behavior, purchase decision, preference, and also use of hierarchical analysis process have gotten a great importance in marketing and also are considered by many of the marketing researchers. Michel, Lynch and Al-abdali studied about new perspectives on marketing mix program standardization in 1998. After interview with 63 senior managers of some British companies that export their products to Arab countries in Persian Gulf, it is concluded that:

a) The amount of standards which is applied to the marketing mix elements by these companies are depends on target market factors, amount of political stability, intensity of competition, integration of marketing activities, decision-making criteria, and budgeting method of the company.

b) Strategy of the product has a higher standard than other mix elements of marketing.

c) Changes in price and distribution is more common than advertising modification(reformation).

Another study suggest these 6 methods for creating consumer brand or product preference: need association, mood association, subconscious motivation, behavior modification, cognitive processing and model emulation (Alreck \& Settle, 1999).

Undergraduate students in Singapore have done a research about the preference and selection of a bank. In this research, bank selection decision-making process is described in 3 hierarchical levels. Bank selection decision is at the highest level of this hierarchy. The middle level consists of 9 important and effective factors which influence bank selection. The final level includes 5 banks which the students were more familiar with them.

Based on these priorities, there are 3 important factors in the second level of bank selection decision-making process which influence bank selection decision. These factors are high interest rates of saving accounts, nearness (proximity) of bank location, and general quality of the services ( $\mathrm{Ta} \& \mathrm{Ha}, 2000)$.

\section{Research Background}

Some studies about influential (effective) factors of bank selection:

The results show that employees' behavior, possibility of customers' quick access to the banks, and work speed were respectively the most important influencing factors of public bank selection in Isfahan (Ranjbaran \& Gholami, 2006) 
In this research, the prioritization of the bank selection influencing factors show that behavioral and attitudinal factors, technology, financial facilities and physical factors respectively affect on customer preference in private bank selection. But such a prioritization for public bank selection is: behavioral and attitudinal factors, technology, physical factors, and financial facilities. So the behavioral and attitudinal factors have the highest priority in terms of being effective in customers' preference (Safari et al, 2009).

The final results of the last data analysis led to the identification and prioritization of 10 factors:

providing useful advice and consultation, employees, as an organization, providing complementary services, reputation of the organization in customers' minds, organization technologies and processes, previous experiences of the customers, have friendly and intimate relationship with customers, flexibility in the service providing, and complaints handling Amirshahi et al, 2009).

They studied about the decision-making process of bank selection. Based on the factors prioritization, the high interest rate of saving accounts, nearness (proximity) of the bank location, and general quality of the services are the most important influencing factors ( $\mathrm{Ta} \& \mathrm{Ha}, 2000)$.

Nearness (proximity) of the bank is known as the most important factor in this research. The other factors are: friendly behavior of the employees, experience of favorable (desirable) loan, friends and acquaintances recommendation and suggestion (Mason \& Mayer, 2000).

This researcher studied about bank selection criteria in 19 to 24 year-old students in Bahrain. The results show that: existence of ATMs all over the town and the possibility of using them round the clock, bank reputation, and nearness to the park are the most important influential factors in bank selection process (Almosavi, 2001)

\section{Modern Marketing}

Modern marketing starts with identification and measurement (evaluation) of customers unmet needs and demands, and the strategies of service marketing mix are adjusted (regulated) after selecting target markets by systemic approach.

Nowadays, marketing is preferable to advertising. In this regard, " Marketing" can be defined as: "Identification and recognition of transaction parties and understand their mood, their situation and conditions, attract their attention and their trust, and create motivation via appropriate advertising in order to transact with the banks". Banks should put more emphasize on researches about customer needs and their satisfaction level and also on identification of special target markets, they also should actively encourage the identified target markets to use their services.

Services are defined as " Do some affairs which offer a set of benefits and advantages to customers, but in banking system, these services may be offered through (via) devices (ATM), persons (adviser or consultant), or a combination of the two ( the teller).

In marketing, the cost of acquiring a new customer can be 5 times more than the cost of maintaining a current customer (can be 5 times more than the cost of a current customer retention). Satisfied customers can be the best resource of advertising because they introduce and suggest (recommend) the bank to their family, friends, and acquaintances. At the contrary, dissatisfied customers can destroy a business. Studies show that dissatisfied customers transfer their bad experiences to about 10 to 20 persons. This number is 3 times more than the number of people to whom the satisfied customers transfer their good experiences. Some factors such as giving old and torn bills (banknotes) to customers, lack of sufficient and adequate amount of money at the end of the year, modern service systems failures and. Intensify the customer satisfaction and his/her negative advertising.

The important point is that bank marketing programs are not limited solely to audio, visual and video advertising (ads) of public relations units, but this is the quality of branch managers and their employees behavior and performance which can guarantee (assure) the continuity and durance of the customer relationship with the bank and can attract the people to the branches and make them the permanent customers of the bank.

\section{Influential Factors that Affect Attracting the Customers}

Managers' awareness about specific reasons from which the customers go to the bank and also their ability to benefit the customers' interests will accelerate and facilitate attracting the customers. Some of the most important reasons are:

\subsection{Time saving:}

Time is one of the most important factors of selecting a bank. Bank branch managers can make customers to concentrate all their financial activities in the supervised branches through (by) dividing the responsibilities, assigning the employees 
in (to) the counters which are in proportion to (commensurate with) their talent and their ability, and also through allocating some special counters for the customers who are in a hurry.

\subsection{Providing the services rapidly and accurately}

"Speed" and "accuracy" of the bank employees are very important for some of the customers. So bank managers should use those employees who are very rapid and accurate in doing their job and also should control and supervise their works. In this way, customers will consider the bank as "their second safe home".

\subsection{Employees' behavior}

Employees and specially the "tellers" behavior and also their neatness, their personality, their skill and proficiency in doing bank affairs are the most important factors that attract the customers. Customers will be loyal, permanent and creditworthy customers of the bank branch if they feel mutual interest and fondness to the employees or because the bank staff always greet and welcome them respectfully and courteously.

\subsection{Providing special services}

Some of the customers expect their bank to provide special services. Interior design of the bank branch, providing facilities whenever needed, adequate parking around the bank, cleanliness of branch inside, temporary and interim resting places inside of the branch, water-dispenser (water-cooler) devices in the branch, and having heating and cooling systems are the most important factors that persuade a depositor to being a loyal customer.

\subsection{Providing consultative services}

Some of the customers expect the bank managers and employees to advise and help them as compassionate and knowledgeable advisors by providing consultative services. This paves the way for customers to trust the bank and be the loyal and permanent customers.

\subsection{Other factors}

Some customers have other minor expectations from their bank branches, some factors such as getting acquainted with bank managers and employees, good mood of the employees and their good behavior, giving small or memorial gifts such as felt-tip or fountain pens, and wallets with bank logo, greeting and feeling sympathy with customers, accepting the customers out of hours in necessary, can persuade the customers to be loyal.

According to the above, identifying the customers' needs and providing the best services in a proper way in order to create and expand customer loyalty and satisfaction, are very important.

\section{Research Questions}

This research intends to answer the following basic questions:

- What are the influential factors affect on customers bank selection decision?

- How is the ranking of bank selection?

- What is the recognition and identification pattern of influential bank selection factors?

\section{Research Hypotheses}

According to the conceptual model of the research and in order to above questions, the research hypotheses are:

1. Bank employees' behavior factor affects on customers bank selection decision.

2. Bank service charge (expense) factor affects on customers bank selection decision.

3. Providing special bank services factor affects on customers bank selection decision.

4. Bank goodwill and reliability factor affects on customers bank selection decision.

5. Positive image of bank factor affects on customers bank selection decision.

6. Proper orientation factor affects on customers bank selection decision. 
7. The effects of all influential factors on customers' bank selection decision are the same and equal in branches of Fereshtegan financial institute.

\section{Methodology of Research}

This is a descriptive-survey research in terms of applied purposes. The data have been collected by questionnaire and through field method. The statistical population of this study consists of the customers of Fereshtegan financial institute. 120 persons are determined as the sample size based on simple random sampling. Research tool includes standard questionnaire of effective factors which influence customers' bank selection decision. This questionnaire is based on Likert scale which is graded from 1 to 5 . The validity of this study is confirmed by experts and its reliability which is achieved by Ranjbaran and Gholami (1385) through (by) Chronbach's alpha test using spss software is 0/87 and is confirmed in this regard.

Spss software is used in this study to analyze the resulted data. T-test is used for analyzing research questions. The Freidman test is used to analyze the collected data.

\section{Results}

Hypothesis 1: Bank employees' behavior factor affects on customers bank selection decision.

\begin{tabular}{|c|c|c|c|c|c|c|}
\hline Bank employees behavior & t-statistic & Degree of freedom & Level of significance (sig) & The sample mean difference & Low limit & Up limit \\
\hline & $111 / 296$ & 119 & $0 / 00$ & $32 / 75$ & $32 / 1673$ & $33 / 3327$ \\
\hline
\end{tabular}

Above results show that the test statistic is about 11/296, the degree of freedom is 119 , the mean difference is $32 / 75$ and the level of significance is $0 / 01$. Since the sig amount is less than $5 \%(<5 \%)$, so we are $99 \%$ confident that there is a meaningful and significant relationship between Fereshtegan institute employees behavior factor and customers bank selection decision.

Hypothesis 2: Bank service charge (expense) factor affects on customers bank selection decision.

\begin{tabular}{|c|c|c|c|c|c|c|}
\hline Bank service charge & t-statistic & Degree of freedom & Level of significance (sig) & The sample mean difference & Low limit & Up limit \\
\hline & $107 / 340$ & 119 & $0 / 00$ & $16 / 31667$ & $16 / 0157$ & $16 / 6177$ \\
\hline
\end{tabular}

Above results show that the test statistic is about $107 / 340$, the degree of freedom is 119 , the mean difference is $16 / 31667$ and the level of significance is $0 / 01$. Since the sig amount is less than $5 \%(<5 \%)$, so we are $99 \%$ confident that there is a meaningful and significant relationship between bank service charge factor in Fereshtegan institute and customers bank selection decision.

Hypothesis 3: Providing special bank services factor affects on customers bank selection decision.

\begin{tabular}{|l|l|l|l|l|l|}
\hline Providing special bank services & t-statistic & Degree of freedom & Level of significance (sig) & The sample mean difference & Low limit \\
\hline
\end{tabular}

\begin{tabular}{|c|c|c|c|c|c|}
\hline $95 / 398$ & 119 & $0 / 00$ & $16 / 24167$ & $15 / 9045$ & $16 / 5788$ \\
\hline
\end{tabular}

Above results show that the test statistic is about 95/938, the degree of freedom is 119 , the mean difference is $16 / 24167$ and the level of significance is $0 / 01$. Since the sig amount is less than $5 \%(<5 \%)$, so we are $99 \%$ confident that there is a meaningful and significant relationship between providing special bank services factor in Fereshtegan institute and customers bank selection decision.

Hypothesis 4: Bank goodwill and reliability factor affects on customers bank selection decision.

\begin{tabular}{|c|c|c|c|c|c|c|}
\hline Bank goodwill and reliability & t-statistic & Degree of freedom & Level of significance (sig) & The sample mean difference & Low limit & Up limit \\
\hline & $99 / 215$ & 119 & $0 / 00$ & $12 / 3333$ & $12 / 0872$ & $12 / 5795$ \\
\hline
\end{tabular}

Above results show that the test statistic is about $99 / 215$, the degree of freedom is 119 , the mean difference is $12 / 3333$ and the level of significance is 0/01. Since the sig amount is less than $5 \%(<5 \%)$, so we are $99 \%$ confident that 
there is a meaningful and significant relationship between bank goodwill and reliability factor in Fereshtegan institute and customers bank selection decision.

Hypothesis 5: Positive image of bank factor affects on customers bank selection decision.

\begin{tabular}{|c|c|c|c|c|c|c|}
\hline Positive image of bank & t-statistic & Degree of freedom & Level of significance (sig) & The sample mean difference & Low limit & Up limit \\
\hline & $105 / 612$ & 119 & $0 / 00$ & $12 / 39167$ & $12 / 1593$ & $12 / 6240$ \\
\hline
\end{tabular}

Above results show that the test statistic is about 105/612, the degree of freedom is 119 , the mean difference is $12 / 39167$ and the level of significance is $0 / 01$. Since the sig amount is less than $5 \%(<5 \%)$, so we are $99 \%$ confident that there is a meaningful and significant relationship between positive image of bank factor in Fereshtegan institute and customers bank selection decision.

Hypothesis 6: Proper orientation factor affects on customers bank selection decision.

\begin{tabular}{|c|c|c|c|c|c|c|}
\hline Proper orientation & t-statistic & Degree of freedom & Level of significance (sig) & The sample mean difference & Low limit & Up limit \\
\hline & $106 / 340$ & 119 & $0 / 00$ & $12 / 29167$ & $12 / 0628$ & $12 / 5205$ \\
\hline
\end{tabular}

Above results show that the test statistic is about 106/340, the degree of freedom is 119 , the mean difference is $12 / 29167$ and the level of significance is $0 / 01$. Since the sig amount is less than $5 \%(<5 \%)$, so we are $99 \%$ confident that there is a meaningful and significant relationship between proper orientation of Fereshtegan institute and customers bank selection decision.

Hypothesis 7: The effects of all influential factors on customers' bank selection decision are the same and equal in branches of Fereshtegan financial institute.

The Friedman test is used to check the equality of the prioritization (ranking) of some independent variables.

Table 1: Factors ranking

\begin{tabular}{|l|c|c|}
\hline Influential factors which affect the customers bank selection decision & The mean scores of each factor & The score of each factor \\
\hline Bank employees behavior & 6 & 1 \\
\hline Bank service charge & $4 / 47$ & 2 \\
\hline Providing special bank services & $4 / 41$ & 3 \\
\hline Bank goodwill and reliability & $1 / 97$ & 6 \\
\hline Positive image of bank & $2 / 12$ & 4 \\
\hline Proper orientation & $2 / 03$ & 5 \\
\hline
\end{tabular}

Table 2: Freidman test results

\begin{tabular}{|l|c|}
\hline Numbers & 120 \\
\hline Chi square statistic & $523 / 963$ \\
\hline Degree of freedom & 5 \\
\hline Level of significance (sig) & $0 / 00$ \\
\hline
\end{tabular}

According to the amount of sig, since the level of significance is less than $0 / 05(<0 / 05)$, so the hypothesis 7 is rejected and the claim equality of the prioritization is not accepted. Based on the mean scores of factors we can say that the employees' behavior factor has the highest utility and priority and the bank reliability and creditworthy has the lowest utility and priority. According to the results, the following model is suggested for identifying the factors which influence the bank selection decision. 


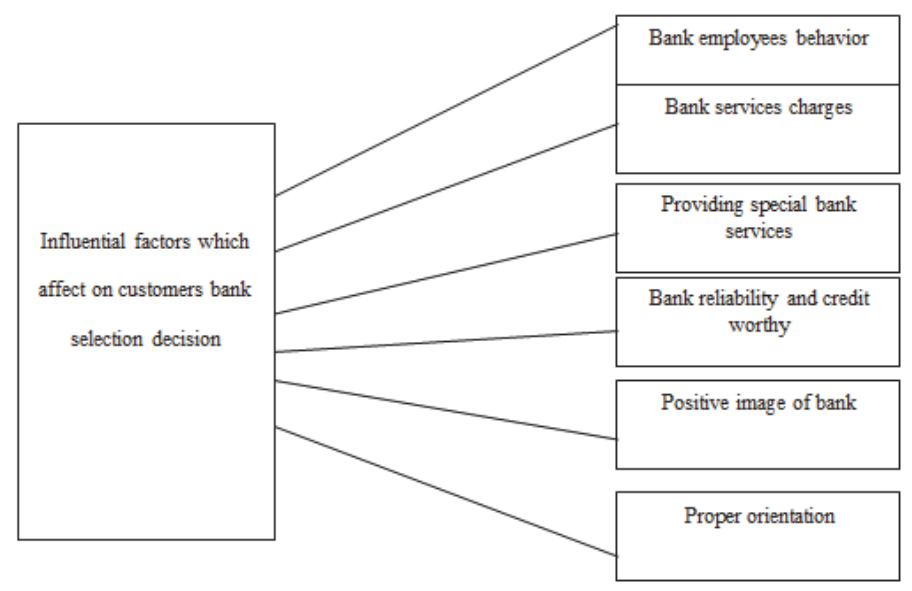

Model 2: Research model

\section{Conclusion}

According to statistical analyses of this research there is a positive and meaningful relationship between the factors (employees' behavior, bank service charges, providing special services, bank reliability and creditworthy, positive image of bank, appropriate orientation) and bank selection decision of Fereshtegan institute customers. Also based on Freidman test, the prioritization of these factors is not the same and equal. Considering the mean scores of each factor, it is resulted that employees' behavior factor has the highest priority and bank reliability and creditworthy factor has the lowest priority.

Therefore, we think that customer-oriented should be dominate on bank activities, and bank employees- especially who are in direct contact with customers- should be trained regarding employees behavior management, how to solve customers problems, respect the customers, and notice to their comments and opinions. The institute also can identify the unsatisfied needs of the customers by establishing a new section in organization for marketing and for market researches and this can be a very influential factor by itself.

\section{Suggestions for Future Researches}

- Although data collecting in this research is done based on the resulted data of the questionnaires which were filled by bank customers, but it is suggested to use other tools such as observation or another standard questionnaire with other indices to investigate the variables.

- It is suggested to use a researcher made tool with identified indices for future researches.

- It is suggested to do comparative studies to compare the achieved results of this institute with other financial institutions.

\section{Resources}

Moon.C.J and Minor.S.M. Customer behavior (Translation by: Abbas saleh Ardestani), Tehran, Asaar publication, Publishing year of the original work, 1993.

Ranjbaran, bahram and Gholami, mahmood (2006): Study of the effective factors and customers preferences for a state bank choice (A case study: Esfahan)

Safari, Saeid et al (2009): Comparative study of influential factors affecting on customers preferences for selecting a public or private bank, Development and management behavior, scientific- research journal of Shahed university, new vol, no.38.

Amirshahi, Mirahmad et al (2009): Identifying the effective factors creating trust among the key bank customers (Tehran Kaar afarin bank), Management researches in Iran, vol 13, no.4, winter 2009.

Michel, P., \& Lynch, Jo, \& AL abdali, O. (1998). New Perspective On marketing mix program standardization. Internationae Business 
Review,7, $617-634$.

Ta, H. P. \& Har, K. Y. (2000). A study of bank selections in Singapore using the Analytical Hierarchy Process. International Journal of Bank Marketing, 18 (4), 170 - 180.

Alreck, L.P., \& Settle, B. R. (1999) Strategies for building consumer brand preference. Journal of Product \& Brand Management, 8 (2), 130-144.

Almossawi, M. (2001) Bank selection criteria employed by college students in Bahrain: An empirical analysis. International Journal of Bank Marketing, 19 (3), 115 - 125.

Mason, J. B., \& Mayer, M. L. (1974) Differences between high and low income savings and checking account customers. The Magazine of Bank Administration, pp.48 - 52.

Erdener Kaynak, Talha D.Harcer, "American consumers attitudes towards commercial banks", the international jurrnal of bank marketing, vol.23, no.1, 2005, pp.73 - 89. 